\title{
Intracoronary Brachytherapy, a Promising Treatment Option for Diabetic Patients: Results From a European Multicenter Registry (RENO)
}

\author{
Christoph K. Naber, ${ }^{1 *}$ MD, Dietrich Baumgart, ${ }^{1} \mathrm{MD}$, Raoul Bonan, ${ }^{2} \mathrm{MD}$, Karl Wegscheider, ${ }^{3} \mathrm{PhD}$, \\ Patrick W. Serruys, ${ }^{4}$ MD, PhD, Antonio Colombo, ${ }^{5}$ MD, Sigmund Silber, ${ }^{6} \mathrm{MD}$, Eric Eeckhout, ${ }^{7} \mathrm{MD}$, \\ Holger Eggebrecht, ${ }^{1}$ MD, Raumund Erbel, ${ }^{1}$ MD, and Philip Urban, ${ }^{8}$ MD
}

\begin{abstract}
Despite advances in the interventional treatment of coronary disease, diabetics still have double the case fatality rate as nondiabetics. The purpose of this analysis from the Radiation in Europe With Novoste (RENO) registry was to assess the clinical and angiographic 6-month outcome of diabetic patients in comparison to nondiabetic patients after localized $\beta$-radiation. A total of 1,098 patients $(83.8 \%$ with in-stent restenosis) treated with the Novoste Beta-Cath system in Europe were enrolled in the RENO registry. Diabetes was, irrespective of the type of lesion treated, no significant risk factor for major adverse cardiac events or target vessel revascularization. Individuals with diabetes $(\mathbf{n}=$ 256) and without diabetes $(n=833)$ displayed no significant differences concerning clinical or angiographic endpoints. Vascular brachytherapy appears to be the first technique to even out the increased risk of diabetic patients undergoing percutaneous coronary interventions in the routine clinical setting. Thus, intracoronary brachytherapy represents a promising treatment option for diabetic patients. Catheter Cardiovasc Interv 2004;61:173-178. ๑ 2004 Wiley-Liss, Inc.
\end{abstract}

Key words: in-stent restenosis; diabetics; brachytherapy; percutaneous transluminal coronary angioplasty

\section{INTRODUCTION}

Cardiovascular disease is the major cause of morbidity and mortality in patients with diabetes. Diabetic individuals have a two- to fourfold risk for vascular disease than nondiabetics. Diabetes mellitus has a negative impact on mortality and morbidity following catheter-based coronary procedures as well as coronary artery bypass surgery $[1,2]$. Recent advances in the treatment of coronary disease have improved survival for diabetics and nondiabetics, but diabetics still have double the case fatality rate as nondiabetics [3]. Determinants such as high atherosclerosis burden, complex lesion morphology, small target vessel size, and a higher rate of multivessel disease may predispose to the observed excess restenosis rates, which remain the major limitation of catheter-based coronary interventions among patients with diabetes mellitus, irrespective of whether the treatment is performed in native vessels [4-8], saphenous vein grafts [9], or instent restenosis [10-12]. Particular for the treatment of in-stent restenosis, intracoronary brachytherapy is currently the only effective tool to reduce the excess restenosis rates of $19-83 \%$ [13] significantly by $40-60 \%$ [14-18]. Interestingly, recent subanalyses from clinical brachytherapy trials demonstrated for the first time that diabetics appear to profit at least to the same extent from percutaneous interventions as compared to nondiabetic patients [19]. This finding was independent of the type of

${ }^{1}$ West German Heart Center, University Hospital Essen, Essen, Germany

${ }^{2}$ Institut de Cardiologie de Montreal, Montreal, Canada

${ }^{3}$ Institute for Statistics and Econometry, University of Hamburg, Hamburg, Germany

${ }^{4}$ Department of Cardiology, Thoraxcenter, Rotterdam, The Netherlands

${ }^{5}$ Department of Interventional Cardiology, Centro Cuore Columbus Hospital, Milan, Italy

${ }^{6}$ Cardiology Practice in the Dr. Muller Hospital, Munich, Germany

${ }^{7}$ Cardiology Clinic, Centre Hospitalier Universitaire Vaudois, Lausanne, Switzerland

${ }^{8}$ Service de Cardiologie, Hopital de la Tour, Meyrin, Geneva, Switzerland

*Correspondence to: Dr. Christoph K. Naber, Department of Cardiology, University Clinic Essen, Hufelandstr. 55, 45122 Essen, Germany. E-mail: christoph.naber@uni-essen.de

Received 28 March 2003; Revision accepted 25 October 2003

DOI 10.1002/ccd.10795

Published online in Wiley InterScience (www.interscience.wiley.com). 
radiation and could be observed after $\beta$ - as well as after $\gamma$-radiation $[20,21]$. It is thus tempting to speculate on whether such a favorable outcome of diabetic patients following catheter-based coronary procedures can be observed also in the clinical routine setting, besides the potential selection bias of controlled clinical trial populations. The purpose of this analysis was to assess the clinical and angiographic outcome 6 months after localized $\beta$-radiation ( ${ }^{90}$ strontium/yttrium) in diabetic patients with predominantly long diffuse in-stent restenosis from the Radiation in Europe With Novoste (RENO) registry. RENO enrolled the first 1,100 patients treated with the Novoste Beta-Cath system in Europe and therefore perfectly mirrored the clinical routine situation during the enrollment period from June 1999 to September 2000. As the reduction of restenosis rate and target vessel revascularization (TVR) was well comparable to those of randomized brachytherapy trials, the RENO registry has proven that these results can be successfully achieved also in the routine clinical setting [22].

\section{MATERIALS AND METHODS}

The RENO registry was a postmarket prospective surveillance study enrolling 1,098 consecutive patients at 46 European centers treated with conventional interventional therapies followed by localized $\beta$-radiation using the Novoste Beta-Cath system. Patients with de novo or restenotic lesions and objective evidence of ischemia were treated with approved interventional procedures (balloon angioplasty, percutaneous rotational atherectomy (PTRA), excimer laser coronary angioplasty (ELCA), directional coronary atherectomy (DCA), and stenting) followed by ${ }^{90}$ strontium radiation treatment (Novoste Beta-Cath system). Patient enrollment occurred from 1 June 1999 to 27 September 2000.

Detailed proceedings have been published elsewhere [22]. In brief, baseline and clinical data were collected on standardized case report forms at the clinical sites. Clinical follow-up was mandated at 1 and 6 months. Angiographic follow-up at 6 months was not mandated, however, but is available on $72.4 \%$ of the patients.

The primary endpoint of the study was procedural success without occurrence of major adverse cardiac events (including death, myocardial infarction, revascularization of the target vessel) after 6 months. After successful completion of the interventional procedure, the angioplasty catheter was withdrawn. Next, the BetaRail delivery catheter was positioned and radiation therapy was performed as described [22] with a recommended dose prescription of 18.4 to $23 \mathrm{~Gy}$ at $2 \mathrm{~mm}$ from the radiation source depending on the vessel diameter.

All RENO patients received a combination treatment of aspirin $(100 \mathrm{mg})$ and clopidogrel/ticlopidine. The du- ration of treatment was, however, determined by the respective operator's routine use of this combination. From the steering committee, a 6-month combination treatment was recommended. Based on the results, $70 \%$ of patients received the combination treatment for longer than 6 months. The remaining patients received a combination treatment for 3-6 months.

Baseline demographic and clinical variables were descriptively summarized. Diabetic and nondiabetic patients were assessed for comparability at baseline and follow-up using chi-square tests or Fisher's exact test for nominal variables and exact Mann-Whitney U-tests for continuous variables. Odds ratios and $95 \%$ confidence intervals for diabetes vs. nondiabetes were calculated for the outcome variables 6-month MACE and TVR or 6-month binary restenosis using logistic regression models, either adjusted or unadjusted for 17 baseline variables (age, gender, unstable angina, bypass graft, in-stent restenosis, chronic total occlusion, new stent placement, cutting balloon used, final residual stenosis, reference diameter, lesion length, maximum balloon size, applied dose, total radiated length, ratio of lesion length to radiated length, pullback procedure used, and geographic miss). All statistical analyses were performed using SPSS 10.0 .7 by SPSS. A $P$ value of $\leq 0.05$ is regarded as statistically significant.

\section{RESULTS}

Baseline demographic data are presented in Table I. There were more female patients and less current smokers in the diabetic group. Diabetics were slightly older, and there were more diabetic patients with multivessel disease.

Angiographic and interventional parameters are displayed in Table II. Lesion characteristics and procedural data were not significantly different between the groups. The pattern of in-stent restenosis categorized as focal, at the stent ends, or diffuse was similar between diabetic (18.3\% vs. $3.3 \%$ vs. $78.4 \%)$ and nondiabetic patients ( $16.5 \%$ vs. $5.3 \%$ vs. $78.2 \%$, respectively; $P=0.4)$. The applied dose was slightly lower in the diabetic patients, and a regression model with mean radiation dose as response variable and diabetes and vessel diameter as regressors reveals that this difference persists after adjustment for vessel diameter. The odds ratio for MACE was $0.94 / \mathrm{Gy}$ in diabetic and nondiabetic patients.

There were no differences between the groups regarding technical success rates and in-hospital events. The 6-month clinical and angiographic follow-up including the in-hospital events are displayed in Table III. With respect to the clinical and angiographic outcome after 6 months, no significant differences could be observed between the groups (Table III and Fig. 1). Odds ratios of 
TABLE I. Demographic and Clinical Data

\begin{tabular}{|c|c|c|c|c|c|c|}
\hline \multirow[b]{2}{*}{ Parameter } & \multicolumn{2}{|c|}{ All } & \multicolumn{2}{|c|}{ In-stent restenosis } & \multicolumn{2}{|c|}{ De novo lesions } \\
\hline & Diabetes & No diabetes & Diabetes & No diabetes & Diabetes & No diabetes \\
\hline $\mathrm{n}$ & 256 & 833 & 209 & 657 & 35 & 143 \\
\hline Sex (male) & $69.1^{\mathrm{a}}$ & 78.8 & $70.3^{\mathrm{a}}$ & 77.8 & 68.6 & 80.4 \\
\hline Age (years) & $63.8 \pm 9.8^{\mathrm{a}}$ & $61.5 \pm 10.2$ & $64.1 \pm 10.0$ & $61.6 \pm 10.5$ & $60.9 \pm 9.1$ & $61.2 \pm 9.5$ \\
\hline Prior MI & 35.2 & 36.3 & 36.7 & 38.2 & 26.5 & 27.5 \\
\hline Multivessel disease & $62.1^{\mathrm{a}}$ & 46.3 & $61.7^{\mathrm{a}}$ & 45.1 & 62.9 & 50.3 \\
\hline$>$ one vessel treated & 4.3 & 6.6 & 3.8 & 5.2 & 8.6 & 11.9 \\
\hline Unstable angina & 30.5 & 25.7 & 28.7 & 23.5 & 32.4 & 32.5 \\
\hline Hyperlipidemia & 81.5 & 76.6 & 81.6 & 79.3 & 80.0 & 62.9 \\
\hline Current smoking & $12.2^{\mathrm{a}}$ & 17.0 & 11.0 & 14.7 & 23.5 & 26.1 \\
\hline
\end{tabular}

${ }^{\mathrm{a}} P \leq 0.05$ vs. no diabetes.

TABLE II. Angiographic Data

\begin{tabular}{|c|c|c|c|c|c|c|}
\hline \multirow[b]{2}{*}{ Parameter } & \multicolumn{2}{|c|}{ All } & \multicolumn{2}{|c|}{ In-stent restenosis } & \multicolumn{2}{|c|}{ De novo lesions } \\
\hline & Diabetes & No diabetes & Diabetes & No diabetes & Diabetes & No diabetes \\
\hline Treated vessels & 267 & 897 & 217 & 694 & 38 & 168 \\
\hline Lesion length (mm) & $18.7 \pm 11.4$ & $19.1 \pm 11.9$ & $18.9 \pm 11.7$ & $19.7 \pm 12.6$ & $18.0 \pm 11.0$ & $17.4 \pm 9.3$ \\
\hline Reference diameter (mm) & $3.2 \pm 0.5$ & $3.2 \pm 0.5$ & $3.2 \pm 0.4$ & $3.2 \pm 0.5$ & $3.1 \pm 0.5$ & $3.2 \pm 0.5$ \\
\hline In-stent restenosis & 80.8 & 76.7 & 100.0 & 100.0 & 0.0 & 0.0 \\
\hline Bypass & 7.9 & 5.4 & 7.8 & 5.1 & 5.3 & 6.0 \\
\hline Cutting balloon & 17.6 & 14.0 & 20.7 & 17.3 & 0.0 & 1.2 \\
\hline New stent & 26.2 & 30.6 & 15.2 & 19.3 & 81.6 & 75.6 \\
\hline Technical success & 96.9 & 95.5 & 96.7 & 95.2 & 97.3 & 96.4 \\
\hline Geographic miss & 6.1 & 6.2 & 5.1 & 6.4 & 13.2 & 6.0 \\
\hline Mean dose (Gy) & $18.4 \pm 3.1^{\mathrm{a}}$ & $19.0 \pm 3.2$ & $18.6 \pm 3.2^{\mathrm{a}}$ & $19.2 \pm 3.1$ & $17.4 \pm 2.9^{\mathrm{a}}$ & $18.4 \pm 3.3$ \\
\hline
\end{tabular}

${ }^{\mathrm{a}} P \leq 0.05$ vs. no diabetes.

TABLE III. Six-Month Clinical and Angiographic Follow-Up Including In-Hospital Events

\begin{tabular}{|c|c|c|c|c|c|c|}
\hline \multirow[b]{2}{*}{ Parameter } & \multicolumn{2}{|c|}{ All } & \multicolumn{2}{|c|}{ In-stent restenosis } & \multicolumn{2}{|c|}{ De novo lesions } \\
\hline & Diabetes & No diabetes & Diabetes & No diabetes & Diabetes & No diabetes \\
\hline $\mathrm{n}$ & 256 & 833 & 209 & 657 & 35 & 143 \\
\hline Death & $7(2.7)$ & $14(1.7)$ & $6(2.9)$ & $11(1.7)$ & $0(0.0)$ & $3(2.1)$ \\
\hline Cardiac & $5(2.0)$ & $7(0.8)$ & $5(2.4)$ & $5(0.8)$ & $0(0.0)$ & $2(1.4)$ \\
\hline MI & $10(3.9)$ & $18(2.2)$ & $7(3.3)$ & $14(2.1)$ & $2(5.7)$ & $3(2.1)$ \\
\hline Q-wave & $4(1.6)$ & $7(0.8)$ & $3(1.4)$ & $5(0.8)$ & $1(2.9)$ & $1(0.7)$ \\
\hline Death or MI & $15(5.9)$ & $30(3.6)$ & $11(5.3)$ & $23(3.2)$ & $2(5.7)$ & $6(4.2)$ \\
\hline TVR & 44 (17.2) & $136(16.1)$ & $31(14.8)$ & $102(15.5)$ & $10(28.6)$ & $28(19.6)$ \\
\hline MACEs & $52(20.3)$ & $152(18.2)$ & $37(17.7)$ & $115(17.5)$ & $11(31.4)$ & $33(23.1)$ \\
\hline
\end{tabular}

6-month MACE for diabetes were $1.14(95 \% \mathrm{CI}=$ $0.8-1.62)$ unadjusted and $1.30(95 \% \mathrm{CI}=0.87-1.93)$ after adjustment for the baseline variables. For TVR or restenosis, odds ratios were $0.93(95 \% \mathrm{CI}=0.65-1.34)$ unadjusted and $0.99(95 \% \mathrm{CI}=0.68-1.45)$ after adjustment. There were no significant interactions between diabetes and any of the baseline variables included.

After stratification for the type of the treated lesion, there were also no significant differences between the groups (Table I and Fig. 2), although diabetic patients with de novo stenosis appeared to have somewhat higher rates of binary restenosis, TVR, and target vessel thrombosis. The odds ratios related to diabetes, stratified for the type of lesion treated, are displayed in Figure 3.

\section{DISCUSSION}

It is not yet clear why diabetic patients have such an unfavorable outcome following catheter-based coronary procedures. Van Belle et al. [23] concluded from their data that restenosis, especially in its occlusive form, is a major determinant of long-term mortality in diabetic patients after coronary balloon angioplasty due to a significant decrease in ejection fraction [24]. Serial IVUS analysis showed that the main reason for increased restenosis in diabetes mellitus was exaggerated intimal hyperplasia in both stented and nonstented lesions [25]. Histopathological analyses from coronary specimens from patients with diabetes mellitus yielded a reduced 


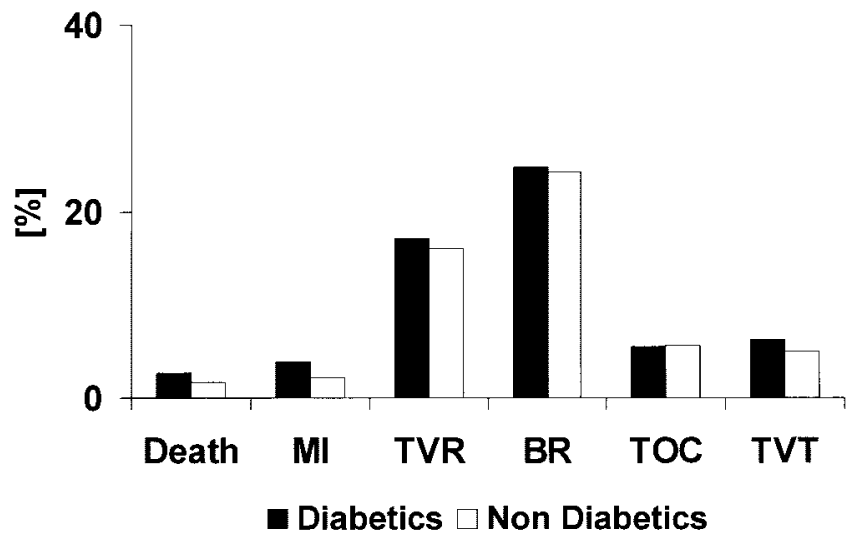

Fig. 1. Clinical and angiographic 6-month follow-up, all patients. BR, binary restenosis ( $>50 \%$ diameter restenosis); TOC, total occlusion of target vessel in angiography; TVT, surrogate composite endpoint of target vessel thrombosis (target vesselrelated cardiac death, MI after 30 days, total target vessel occlusion on angiography).

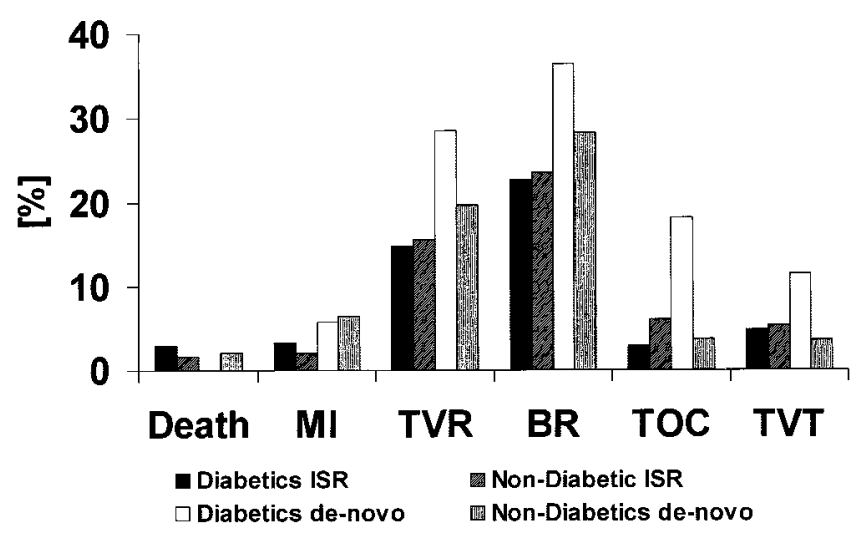

Fig. 2. Clinical and angiographic 6-month follow-up, stratified for initial lesion type. ISR, in-stent-restenosis.

intimal hypercellular tissue content in restenotic tissue from these patients, while collagen-rich sclerotic content was increased [26]. The authors concluded that these results suggest an accelerated fibrotic rather than a proliferative response in diabetic lesions from patients with restenosis after PTCA. On the other hand, Faries et al. [27] demonstrated that diabetic vascular smooth muscle cells (VSMCs) exhibit significantly increased rates of proliferation, adhesion, and migration as well as abnormal cell culture morphology suggestive of abnormal contact inhibition.

For the long term, diabetic patients have remained one of the most challenging tasks in interventional cardiology. The case fatality and restenosis rates were far worse in diabetic than in nondiabetic patients, irrespective of the treatment modality or the nature of the treated lesion [4-13].
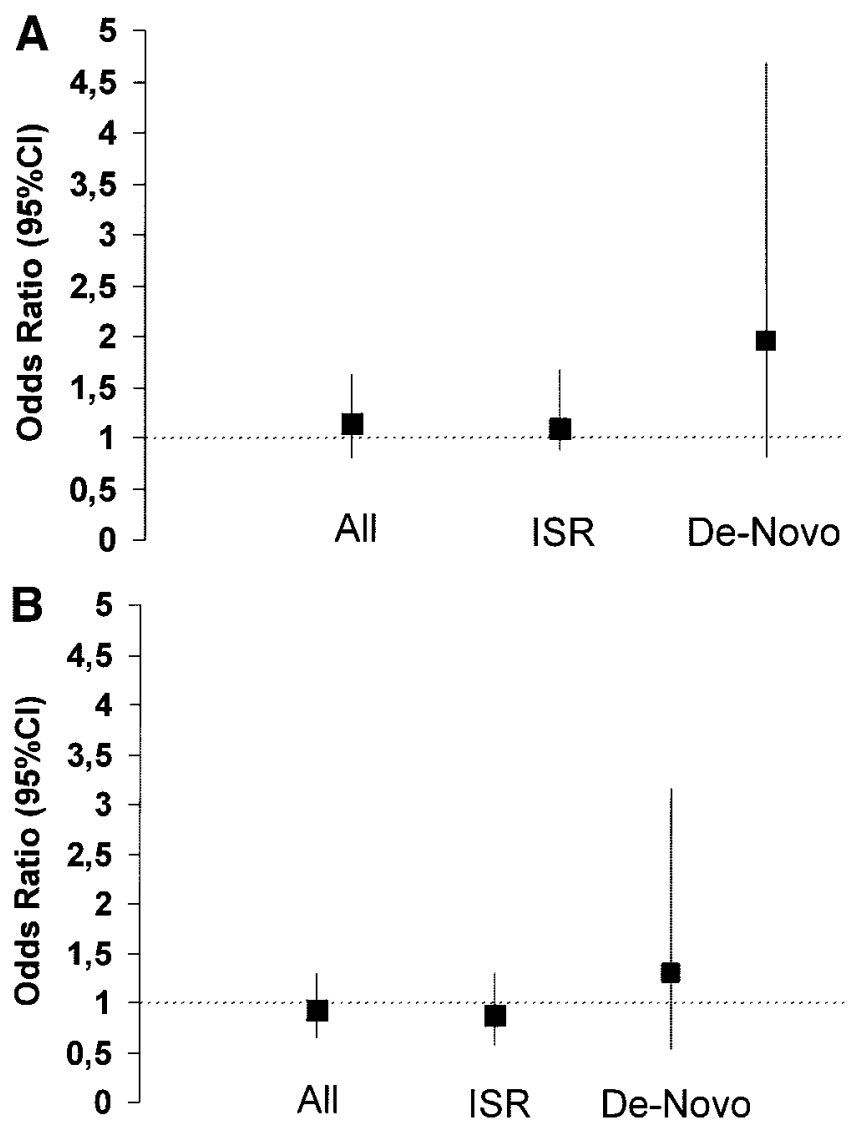

Fig. 3. Odds ratios for diabetes for (A) MACE and (B) TVR/ restenosis.

Recent results from controlled intracoronary brachytherapy trials indicated for the first time that diabetic patients may profit significantly from a catheter-based interventional technique with long-term result comparable to nondiabetic patients. In the Scripps Coronary Radiation to Inhibit Proliferation Poststenting (SCRIPPS) trial, Teirstein et al. [19] showed that in the treatment group, late loss was particularly low in patients with diabetes, a vessel diameter $<3.0 \mathrm{~mm}$, and in-stent restenosis. The authors concluded that in this study, patient characteristics associated with a more aggressive proliferative response to injury appeared to confer an enhanced response to radiotherapy. Similar results were published also for $\beta$-radiation $[20,28]$, and even more surprising were the results from the GAMMA-I trial, which yielded after brachytherapy treatment a reduction in binary restenosis of $16 \%$ in the nondiabetic patients and of even $40 \%$ in the diabetic patients [21].

These findings are clearly supported by the data from the RENO registry reported here, which represents the largest single series of diabetic patients treated with brachytherapy to date. Common risk factors for resteno- 
sis such as lesion length, reference vessel diameter, and type of target lesion were comparable between the groups. Although the diabetic group consisted of significantly more patients with multivessel disease, there were no statistically significant differences regarding the clinical and angiographic outcome between the groups after 6 months. Diabetes was no significant risk factor for MACE and TVR or angiographic restenosis in a multivariate analysis.

Subanalyses of the patients with in-stent restenosis and those with de novo lesions also yielded no significant differences between the groups, although diabetic patients with de novo stenosis appeared to have somewhat higher rates of binary restenosis, TVR, total occlusions, and target vessel thrombosis. On the other hand, these patients received also the lowest mean radiation dose, had the highest rate of geographic miss (inadequate radiation of the interventional injury length), and the highest number of new implanted stents. These facts, and the small number of patients in the RENO de novo group, indicate that the results of this subanalysis should be interpreted with caution.

In conclusion, the above findings indicate, with respect to the expected high case fatality in diabetic patients, that intracoronary brachytherapy represents a promising treatment option for diabetic patients. Vascular brachytherapy appears to be the first percutaneous interventional technique from which diabetic patients profit to at least the same extent that nondiabetic individuals do.

It appears reasonable to assume that the exaggerated intimal hyperplasia is counteracted by the antiproliferatory properties of intracoronary irradiation. Thus, it may be suggested that other antiproliferative therapies can be equally effective to even out the increased risk of diabetic patients undergoing percutaneous coronary interventions.

\section{Study Limitations}

The data entered into this analysis were taken from a large prospective multicenter registry. This registry was not designed to aim at differences between diabetics and nondiabetics undergoing intracoronary radiation. Thus, although our findings confirm findings from prospective studies in clinical practice, the power of the study, especially regarding the subgroup analysis, is not sufficient to show equivalence between the groups.

Another limitation is that due to the design of the RENO registry, there is no information on the type of diabetes or the antidiabetic treatment of the included patients available. Also, no information is available on the number or kind of previous treatments at the target lesion.

\section{REFERENCES}

1. Marso SP, Mak KH, Topol EJ. Diabetes mellitus: biological determinants of atherosclerosis and restenosis. Semin Interv Cardiol 1999;4:129-143.

2. Kornowski R, Lansky AJ. Current perspectives on interventional treatment strategies in diabetic patients with coronary artery disease. Catheter Cardiovasc Interv 2000;50:245-254.

3. Mercado N, Boersma E, Wijns W, Gersh BJ, Morillo CA, de Valk V, van Es GA, Grobbee DE, Serruys PW. Clinical and quantitative coronary angiographic predictors of coronary restenosis: a comparative analysis from the balloon-to-stent era. J Am Coll Cardiol 2001;38:645-652.

4. Abizaid A, Kornowski R, Mintz GS, Hong MK, Abizaid AS, Mehran R, Pichard AD, Kent KM, Satler LF, Wu H, Popma JJ, Leon MB. The influence of diabetes mellitus on acute and late clinical outcomes following coronary stent implantation. J Am Coll Cardiol 1998;32:584-589.

5. Huynh T, Eisenberg MJ, Deligonul U, Tsang J, Okrainec K, Schechter D, Lefkovits J, Mak KH, Brown DL, Brieger D. Coronary stenting in diabetic patients: results from the ROSETTA registry. Am Heart J 2001;142:960-964.

6. Lansky AJ, Roubin GS, O'Shaughnessy CD, Moore PB, Dean LS, Raizner AE, Safian RD, Zidar JP, Kerr JL, Popma JJ, Mehran R, Kuntz RE, Leon MB. Randomized comparison of GR-II stent and Palmaz-Schatz stent for elective treatment of coronary stenoses. Circulation 2000;102:1364-1368.

7. Koster R, Kahler J, Terres W, Reimers J, Baldus S, Hartig D, Berger J, Meinertz T, Hamm CW. Six-month clinical and angiographic outcome after successful excimer laser angioplasty for in-stent restenosis. J Am Coll Cardiol 2000;36:69-74.

8. Schofer J, Schluter M, Rau T, Hammer F, Haag N, Mathey DG. Influence of treatment modality on angiographic outcome after coronary stenting in diabetic patients: a controlled study. J Am Coll Cardiol 2000;35:1554-1559.

9. Wong SC, Baim DS, Schatz RA, Teirstein PS, King SB III, Curry RC Jr, Heuser RR, Ellis SG, Cleman MW, Overlie P. Immediate results and late outcomes after stent implantation in saphenous vein graft lesions: the multicenter U.S. Palmaz-Schatz stent experience. J Am Coll Cardiol 1995;26:704-712.

10. Moustapha A, Assali AR, Sdringola S, Vaughn WK, Fish RD, Rosales O, Schroth G, Krajcer Z, Smalling RW, Anderson HV. Percutaneous and surgical interventions for in-stent restenosis: long-term outcomes and effect of diabetes mellitus. J Am Coll Cardiol 2001;37:1877-1882.

11. Mehran R, Dangas G, Abizaid A, Lansky AJ, Mintz GS, Pichard AD, Satler LF, Kent KM, Waksman R, Stone GW, Leon MB. Treatment of focal in-stent restenosis with balloon angioplasty alone versus stenting: short- and long-term results. Am Heart J 2001;141:610-614.

12. Klugherz BD, Meneveau NF, Kolansky DM, Herrmann HC, Schiele F, Matthai WH Jr, Groh WC, Untereker WJ, Hirshfeld JW Jr, Bassand JP, Wilensky RL. Predictors of clinical outcome following percutaneous intervention for in-stent restenosis. Am J Cardiol 2000;85:1427-1431.

13. Mehran R, Dangas G, Abizaid AS, Mintz GS, Lansky AJ, Satler LF, Pichard AD, Kent KM, Stone GW, Leon MB. Angiographic patterns of in-stent restenosis: classification and implications for long-term outcome. Circulation 1999;1001872-1878.

14. Leon MB, Teirstein PS, Moses JW, Tripuraneni P, Lansky AJ, Jani S, Wong SC, Fish D, Ellis S, Holmes DR, Kerieakes D, Kuntz RE. Localized intracoronary gamma-radiation therapy to inhibit the recurrence of restenosis after stenting. N Engl J Med 2001; $344: 250-256$. 
15. Waksman R, Bhargava B, White L, Chan RC, Mehran R, Lansky AJ, Mintz GS, Satler LF, Pichard AD, Leon MB, Kent KK. Intracoronary beta-radiation therapy inhibits recurrence of in-stent restenosis. Circulation 2000;101:1895-1898.

16. Waksman R, White RL, Chan RC, Bass BG, Geirlach L, Mintz GS, Satler LF, Mehran R, Serruys PW, Lansky AJ, Fitzgerald P, Bhargava B, Kent KM, Pichard AD, Leon MB. Intracoronary gamma-radiation therapy after angioplasty inhibits recurrence in patients with in-stent restenosis. Circulation 2000;101:2165-2171.

17. Waksman R, Raizner AE, Yeung AC, Lansky AJ, Vandertie L. Use of localised intracoronary beta radiation in treatment of instent restenosis: the INHIBIT randomised controlled trial. Lancet 2002;359:551-557.

18. Popma JJ, Suntharalingam M, Lansky AJ, Heuser RR, Speiser B, Teirstein PS, Massullo V, Bass T, Henderson R, Silber S, von Rottkay P, Bonan R, Ho KK, Osattin A, Kuntz RE. Randomized trial of $90 \mathrm{Sr} / 90 \mathrm{Y}$ beta-radiation versus placebo control for treatment of in-stent restenosis. Circulation 2002;106:1090-1096.

19. Teirstein PS, Massullo V, Jani S, Popma JJ, Mintz GS, Russo RJ, Schatz RA, Guarneri EM, Steuterman S, Cloutier DA, Leon MB, Tripuraneni P. A subgroup analysis of the scripps coronary radiation to inhibit proliferation poststenting trial. Int J Radiat Oncol Biol Phys 1998;42:1097-1104.

20. Gruberg L, Waksman R, Ajani AE, Kim HS, White RL, Pinnow EE, Satler LF, Pichard AD, Kent KM, Lindsay J Jr. The effect of intracoronary radiation for the treatment of recurrent in-stent restenosis in patients with diabetes mellitus. J Am Coll Cardiol 2002;39:1930-1936.

21. Moses JW, Moussa I, Leon MB, Teirstein PS, Fish RD, Ellis SG, Nawas D, Kluck B, Giorgianni JA, Donohoe D, Kuntz RE. Effect of catheter-based iridium-192 gamma brachytherapy on the added risk of restenosis from diabetes mellitus after intervention for in-stent restenosis (subanalysis of the GAMMA I randomized trial). Am J Cardiol 2002;90:243-247.

22. Urban P, Serruys P, Baumgart D, Colombo A, Silber S, Eeckhout E, Gershlick A, Wegscheider K, Verhees L, Bonan R. A multicentre European registry of intraluminal coronary beta brachytherapy. Eur Heart J 2003;24:604-612.

23. Van Belle E, Ketelers R, Bauters C, Perie M, Abolmaali K, Richard F, Lablanche JM, McFadden EP, Bertrand ME. Patency of percutaneous transluminal coronary angioplasty sites at 6-month angiographic follow-up: a key determinant of survival in diabetics after coronary balloon angioplasty. Circulation 2001; $1031218-1224$.

24. Van Belle E, Abolmaali K, Bauters C, McFadden EP, Lablanche JM, Bertrand ME. Restenosis, late vessel occlusion and left ventricular function six months after balloon angioplasty in diabetic patients. J Am Coll Cardiol 1999;34:476-485.

25. Kornowski R, Mintz GS, Kent KM, Pichard AD, Satler LF, Bucher TA, Hong MK, Popma JJ, Leon MB. Increased restenosis in diabetes mellitus after coronary interventions is due to exaggerated intimal hyperplasia: a serial intravascular ultrasound study. Circulation 1997;95:1366-1369.

26. Moreno PR, Fallon JT, Murcia AM, Leon MN, Simosa H, Fuster $\mathrm{V}$, Palacios IF. Tissue characteristics of restenosis after percutaneous transluminal coronary angioplasty in diabetic patients. J Am Coll Cardiol 1999;34:1045-1049.

27. Faries PL, Rohan DI, Takahara H, Wyers MC, Contreras MA, Quist WC, King GL, Logerfo FW. Human vascular smooth muscle cells of diabetic origin exhibit increased proliferation, adhesion, and migration. J Vasc Surg 2001;33:601-607.

28. Laskey W. Diabetics subset in START. Presented at the annual meeting of the American Heart Association. New Orleans; 2000. 